\title{
Reproduction, population dynamics and production of Nereis falsa (Nereididae: Polychaeta) on the rocky coast of El Kala National Park, Algeria
}

\author{
Tarek Daas • Mourad Younsi • \\ Ouided Daas-Maamcha • Patrick Gillet • \\ Patrick Scaps
}

Received: 8 January 2010/Revised: 1 July 2010/Accepted: 2 July 2010/Published online: 18 July 2010

(C) Springer-Verlag and AWI 2010

\begin{abstract}
The polychaete Nereis falsa Quatrefages, 1866 is present in the area of El Kala National Park on the East coast of Algeria. Field investigations were carried out from January to December 2007 to characterize the populations' reproductive cycle, secondary production and dynamics. Reproduction followed the atokous type, and spawning occured from mid-June to the end of August/early September when sea temperature was highest $\left(20-23^{\circ} \mathrm{C}\right)$. The diameter of mature oocytes was approximately $180 \mu \mathrm{m}$. Mean lifespan was estimated to about one year. In 2007 , the mean density was 11.27 ind. $\mathrm{m}^{-2}$ with a minimum of 7.83 ind. $\mathrm{m}^{-2}$ in April and a maximum of 14.5 ind. $\mathrm{m}^{-2}$ in February. The mean annual biomass was $1.36 \mathrm{~g} \mathrm{~m}^{-2}$ (fresh weight) with a minimum of $0.86 \mathrm{~g} \mathrm{~m}^{-2}$ in December and a maximum of $2.00 \mathrm{~g} \mathrm{~m}^{-2}$ in June. The population consisted of two cohorts distinguishable from size frequency distributions. One cohort corresponded to the recruitment of 2006 and the other appeared during the study period in September 2007. The annual production of
\end{abstract}

Communicated by H.-D. Franke.

T. Daas · M. Younsi - O. Daas-Maamcha

Laboratoire de Biologie Animale Appliquée,

Département de Biologie, Faculté des Sciences,

Université Badji Mokhtar, 23000 Annaba, Algeria

P. Gillet

Centre d'Etude et de Recherche sur les Ecosystèmes Aquatiques, Institut de Biologie et d'Ecologie Appliquée, UCO,

44, rue Rabelais, Angers, France

P. Scaps $(\bowtie)$

Laboratoire de Biologie Animale,

Université des Sciences et Technologies de Lille,

59655 Villeneuve d'Ascq Cédex, France

e-mail: patrick.scaps@univ-lille1.fr
$N$. falsa was $1.45 \mathrm{~g} \mathrm{~m}^{-2}$ year $^{-1}$, and the production/biomass ratio was 1.07 year $^{-1}$.

Keywords Nereididae - Population dynamics · Production $\cdot$ Reproduction

\section{Introduction}

The polychaete Nereis falsa Quatrefages, 1866 has a wide geographical distribution. This species has been recorded along the coast of the Atlantic Ocean [Atlantic coast of Morocco (Fadlaoui and Retière 1995), Namibia (Glassom and Branch 1997) and South Africa (Day 1967), North American Atlantic coast (Posey et al. 2002, 2006), Florida Bay (Vittor 1997a, 1998), north coast of the Gulf of Mexico (Vittor 1984), Galveston Bay in the Gulf of Texas (Vittor 1997b), north-east coast of Venezuela (Arana and Diaz 2006), Colombian Caribbean coast (Baez and Ardila 2003)] and the Mediterranean Sea [Algésiras Bay in Spain (Sanchez-Moyano et al. 2001), Cueta harbour in Morocco (Guerra-Garcia et al. 2003; Guerra-Garcia and GarciaGomez 2004), Circeo National Park on the Italian Adriatic coast (Andrea and Giancarlo 2003), Izmir Bay/Turkey (Ertan Çinar et al. 2008), on floating debris in the Liguran Sea (Alliani and Meloni 1999) and on current metre moorings deployed in the Corsica Channel (Alliani and Meloni 1999)]. Moreover, this species lives as epibiont on loggerhead turtles (Caretta caretta) nesting on the coast of Georgia, USA (Pfaller et al. 2006), and on mussels Mytilus galloprovincialis in Izmir Bay, eastern Mediterranean (Ertan Çinar et al. 2008). The species is a facultative rafter; i.e. it typically lives in benthic habitats but may become dispersed while being associated with floating items (Thiel and Gutow 2005). 

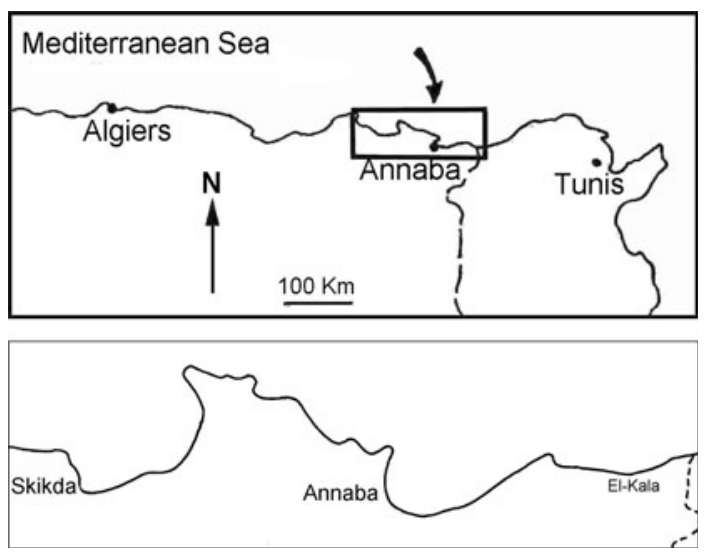

Fig. 1 Study area and location of sampling station

A preliminary study of the species' distribution on the Algerian east coast (between Skikda and El Kala, (Fig. 1) revealed its presence only in the area of El Kala National Park. The reproductive biology and population dynamics of this species are poorly documented. So, this study was conducted to obtain information on the cycle of reproduction, secondary production and dynamics of a population of $N$. falsa on a rocky shore on the Algerian east coast (Mediterranean Sea). This work is part of a research programme dedicated to the identification of indicator species of pollution on the Algerian east coast (Abdenour et al. 2000, 2004; Bouzeraa et al. 2004; Beldi et al. 2006; Sifi et al. 2007).

\section{Materials and methods}

Study site and collection of material

Individuals were collected in the area of El Kala National Park, Algerian east coast. Worms were found among red algae covering hard bottoms. Rocks are metamorphic and are composed of gneiss and quartzite. The maximum tide is small $(0.9 \mathrm{~m})$.

Individuals were collected monthly from January to December 2007. The region sampled corresponded with the area of greatest density of individuals. The individuals occur in the lower intertidal zone and extend down into the subtidal. We used bleaching liquid (10\% in sea water) to force individuals out of their algal mats in order to obtain undamaged whole individuals. Approximately $6 \mathrm{~m}^{2}$ of hard bottom has been monitored each month in order to collect enough individuals for the population dynamics study.

In our study site, $N$. falsa coexists with two other species of nereidid polychaetes, Perinereis cultrifera and Platynereis dumerilii. For a correct identification to species level, using the diagnostic patterns of paragnaths on the proboscis, worms were made to evert their proboscis by generating pressure some distance behind the head.

The number of collected specimens varied between 47 in April and 87 in February. A total of 812 worms were collected and examined. At each sampling date, air and sea water temperature were recorded.

\section{Reproduction}

For the study of the reproductive cycle, the individuals were fixed in the laboratory with $8 \%$ neutral formalin and examined for the presence sexual products in the coelom. A short incision was made in the body wall at about the twentieth chaetigerous segment and a drop $(\sim 1 \mathrm{ml})$ of the coelomic fluid was taken out with a Pasteur pipette and examined under a binocular microscope. If possible, forty oocytes each were measured using a calibrated eye piece graticule. The longest and the shortest diameter of oocytes were determined, and the average value was used as an estimate of oocyte size.

\section{Population dynamics}

After species identification, the fresh weight of each individual was measured. Weight frequency histograms were treated by FISAT II FAO software, which is used for the identification of parameters of a mixture of distributions (Gayanilo et al. 2005) and replaces the methods based on the analysis of modes of histograms (Gayanilo et al. 1988; Gayanilo and Pauly 1989). The secondary production (P) was estimated by the method of Crisp (1971) using the equation $P=\left(\mathrm{Nt}_{1}+\mathrm{Nt}_{2}\right) / 2\left(\mathrm{Wt}_{2}-\mathrm{Wt}_{1}\right)$ with $\mathrm{Nt}_{1}$ and $\mathrm{Nt}_{2}$ representing numbers of individuals in a cohort at times $\mathrm{t}_{1}$ and $t_{2}$ and $\mathrm{Wt}_{1}$ and $\mathrm{Wt}_{2}$ representing the mean fresh weights of a cohort at times $t_{1}$ and $t_{2}$. The secondary production and the production/biomass ratio $(\mathrm{P} / \mathrm{B})$ were calculated for the year 2007 .

\section{Results}

Temperature at the study site (Fig. 2)

During the study period from January to December 2007, air temperature varied between $10^{\circ} \mathrm{C}$ in December and $34^{\circ} \mathrm{C}$ in August (average: $21.08 \pm 9.40^{\circ} \mathrm{C}$ ). Sea water temperature measured during low tide ranged between $8^{\circ} \mathrm{C}$ in January and $23^{\circ} \mathrm{C}$ in August (average: $16.08 \pm 5.01^{\circ} \mathrm{C}$ ). 


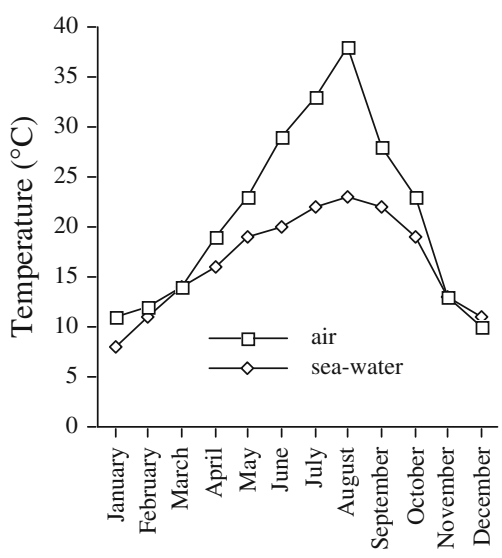

Months

Fig. 2 Monthly sea water and air temperature in the studied area
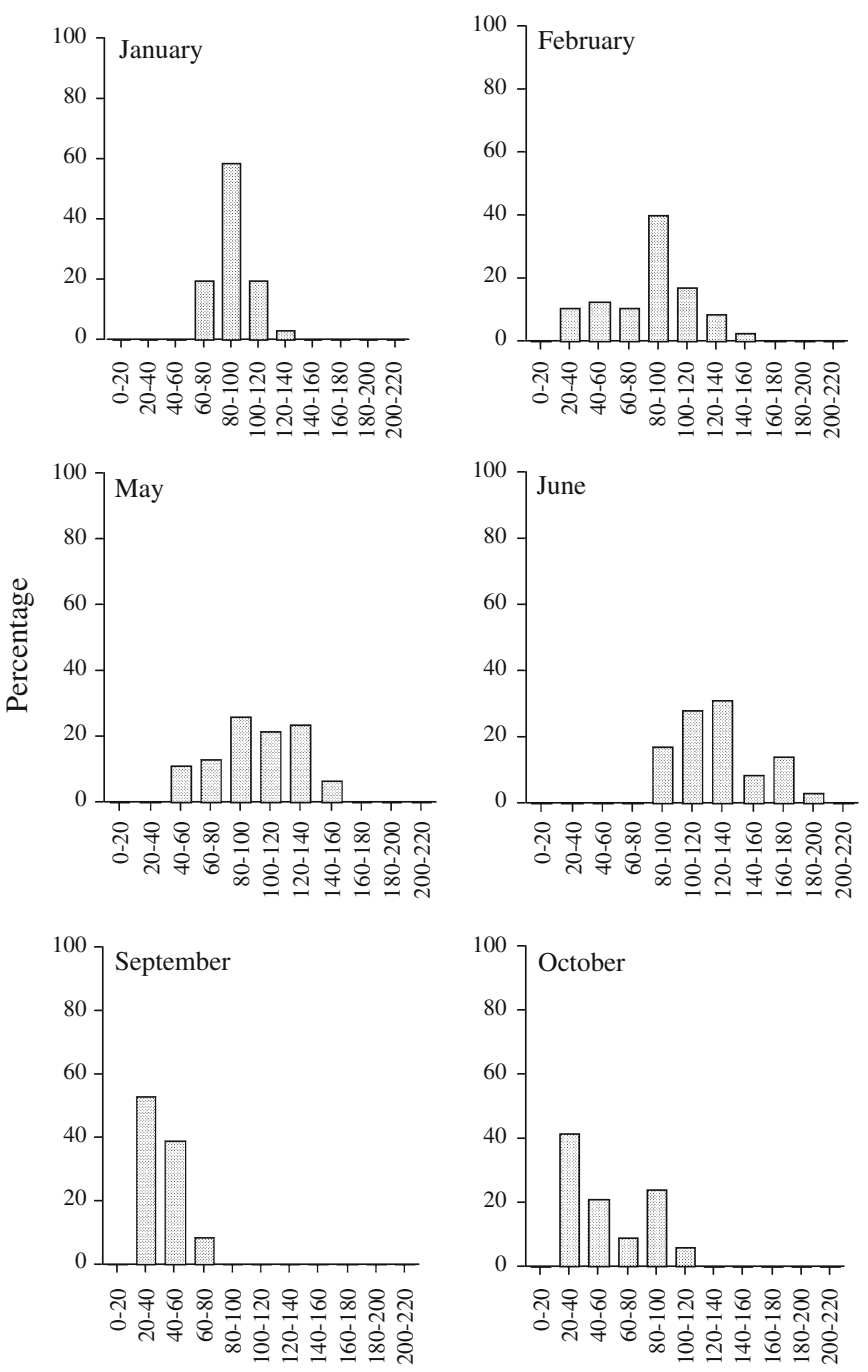

Oocyte diameter $(\mu \mathrm{m})$

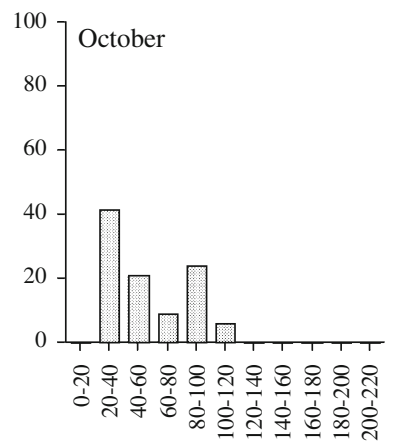

Oocyte diameter $(\mu \mathrm{m})$
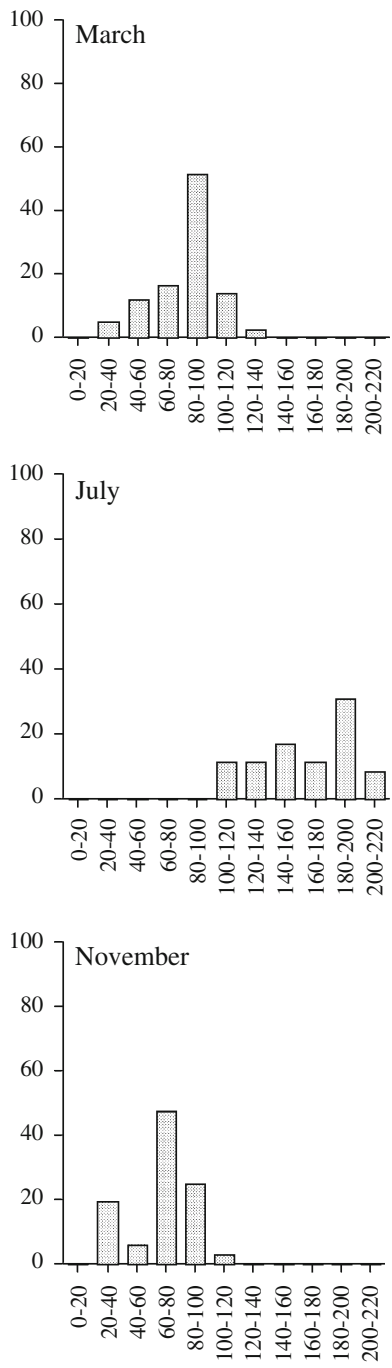

Oocyte diameter $(\mu \mathrm{m})$
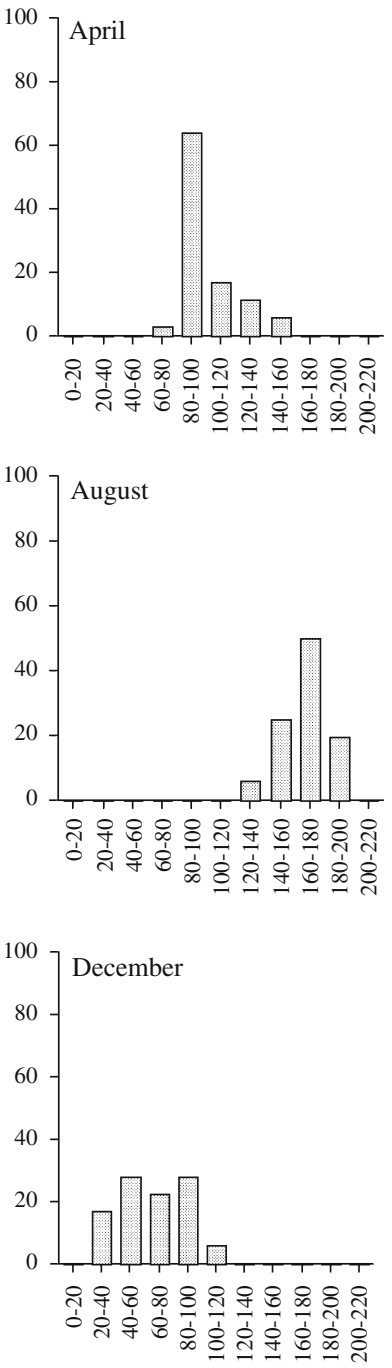

Oocyte diameter $(\mu \mathrm{m})$

Fig. 3 Size distribution frequency of oocytes between January and December 2007 
values of $155 \mu \mathrm{m}$. The first mature oocytes (diameter greater than $160 \mu \mathrm{m}$ ) occurred in the cœlomic fluid of females collected in mid-June. From July to August, oocyte growth was weak and the mean oocyte diameter became maximal $(166.27 \mu \mathrm{m})$. The coelomic fluid of females collected in early August contained a majority of large oocytes (diameter between 120 and $200 \mu \mathrm{m}$ ) (Fig. 3), while the coelomic fluid of females collected in September contained only small oocytes indicating that the spawning period was finished. So, the spawning season begins in mid-June and spreads out until the end of August or early September. From September to December, the mean oocyte diameter ranged between 40 and $60 \mu \mathrm{m}$ and remained relatively constant. Oocytes took less than one year to develop fully (Fig. 4).

During the whole study period, we did not find large mature males or females showing morphological modifications characteristic of epitoky. In consequence, individuals seem to reproduce exclusively in the atokous state and neither of sex appears to survive spawning. A comparison of Figs. 2 and 4 shows that spawning occurs when sea water surface temperature is highest $\left(20-23^{\circ} \mathrm{C}\right)$.

\section{Population dynamics}

The mean density and biomass of $N$. falsa, at the study site between January and December 2007, were $11.27 \pm 2.09$ ind. $\mathrm{m}^{-2}$ and $1.36 \pm 0.38 \mathrm{~g} \mathrm{~m}^{-2}$, respectively. From one month to another, $N$. falsa density and biomass varied considerably (Fig. 5a, b). Nevertheless, the biomass tended to be higher in summer than in winter (Fig. 5b), with the highest value recorded in June $\left(B=2 \mathrm{~g} \mathrm{~m}^{-2}\right)$ and the lowest in December $\left(B=0.86 \mathrm{~g} \mathrm{~m}^{-2}\right)$.

The mean individual fresh weight was maximal during spring and summer (March to August). It decreased at the end of summer (September) and was minimal during

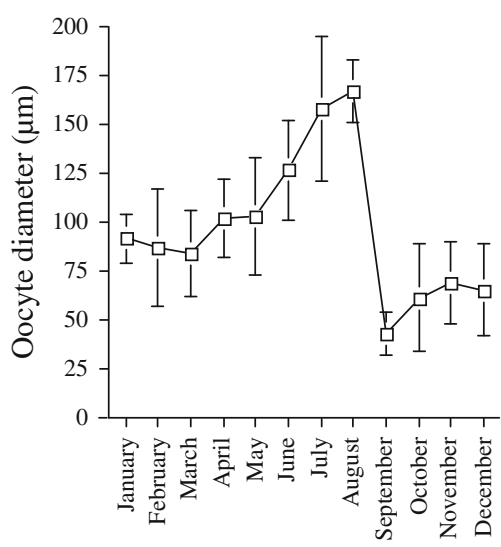

Months

Fig. 4 Changes in oocyte size from January to December 2007. Each data point represents mean $\pm \mathrm{SD}$ of the mean autumn and winter (October to February) (Fig. 6), reflecting the mortality of adults and recruitment of juveniles. The temporal variation in biomass is largely explained by the variation in mean individual fresh weight.

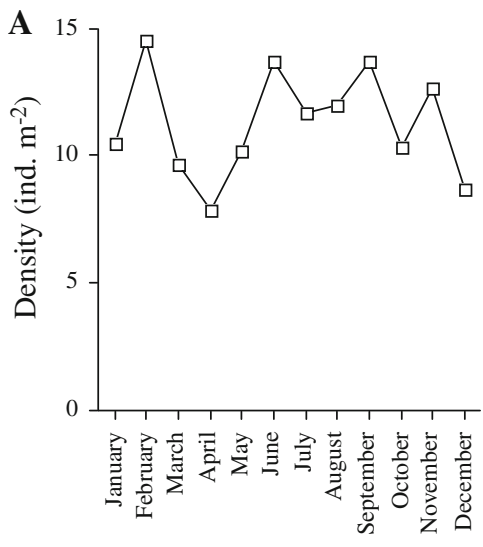

Months

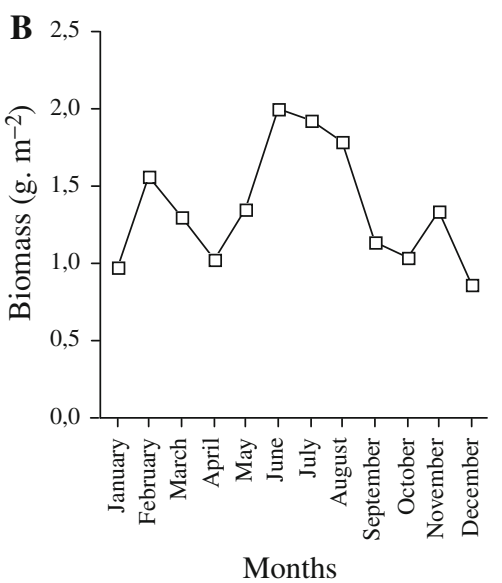

Fig. 5 Temporal variations in the density (ind. $\mathrm{m}^{-2}$ ) (a) and in the biomass (fresh weight $\mathrm{g} \mathrm{m}^{-2}$ ) (b) of the studied population of Nereis falsa at El Kala, Algeria

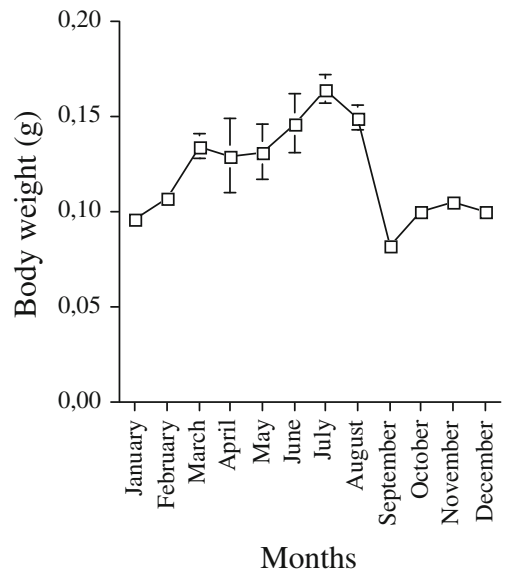

Fig. 6 Changes in the mean individual fresh weight from January to December 2007. Each data point represents mean \pm standard error of the mean 


\section{Recruitment pattern}

The weight frequency histograms of $N$. falsa collected from January to December 2007 are shown in Fig. 7. Two cohorts $\left(\mathrm{C}_{1}, \mathrm{C}_{2}\right)$ can be distinguished. One cohort $\left(\mathrm{C}_{1}\right)$ could be followed over eight months from January to August 2007. This cohort represents the older (I-group) individuals. Its members showed a progressive increase in mean individual weight from January to August (Fig. 6). During summer, this cohort was well represented by large females with large oocytes ranging from 140 to $190 \mu \mathrm{m}$ in diameter in August. In September, the mean individual weight decreased, related to the disappearance of the large individuals after reproduction $\left(\mathrm{C}_{1}\right)$ and the appearance of another cohort $\left(\mathrm{C}_{2}\right)$. This cohort could be followed for the rest of the sampling period into December. It corresponded to a new generation of individuals (0-group; i.e. individuals hatched during the sampling year) which had just settled in the study area. This cohort was represented by females with small oocytes ranging from 30 to $70 \mu \mathrm{m}$ in diameter in September. All frequency histograms showed a unimodal distribution (Fig. 7).

Growth curves (Fig. 8) have been constructed using the means of fresh weight for each cohort shown in Fig. 7. The mean lifespan was estimated to be one year using the appearance and disappearance of modes in the cohort analysis.
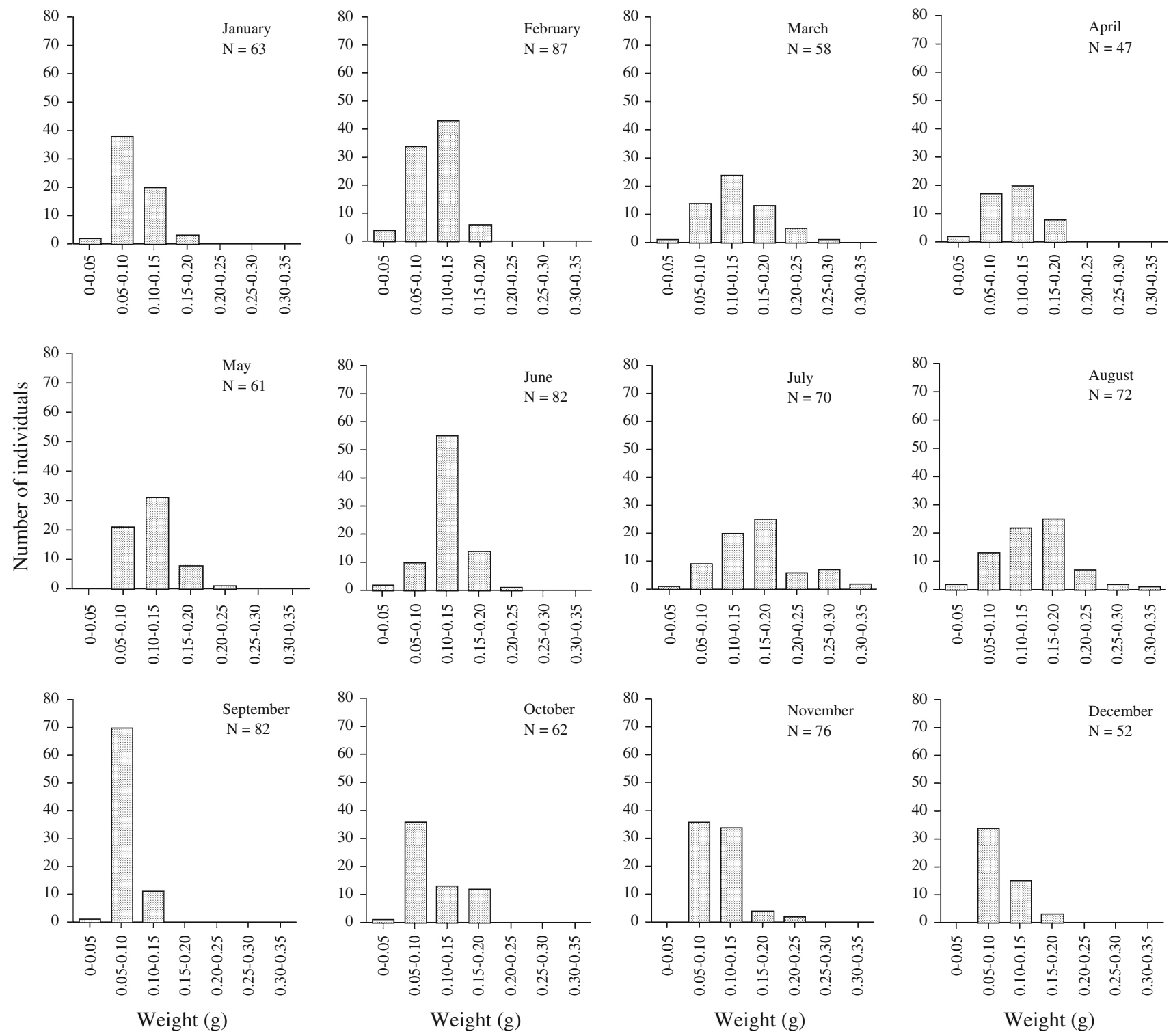

Fig. 7 Weight frequency histograms of Nereis falsa at El Kala between January and December 2007 


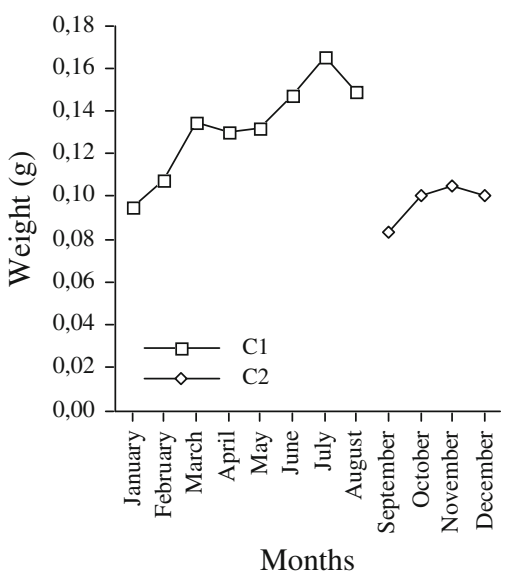

Fig. 8 Growth curves of the cohorts of Nereis falsa at El Kala between January and December 2007

\section{Production estimates}

Estimates for the production by the two cohorts of $N$. falsa during the study period are shown in Table 1 . The annual secondary production in 2007 was $P=1.45 \mathrm{~g} \mathrm{~m}^{-2}$ year $^{-1}$ at a mean annual biomass of $B=1.36 \mathrm{~g} \mathrm{~m}^{-2}$. Thus, the ratio $P / B$ amounted to 1.07 year $^{-1}$.

\section{Discussion}

The reproduction of $N$. falsa in the El Kala National Park (Mediterranean, eastern Algeria) follows the atokous type.

Table 1 Secondary production of the cohorts of the population

\begin{tabular}{llcclc}
\hline Cohort & $\mathrm{Wt}$ & $\mathrm{Wt}_{2}-\mathrm{Wt}_{1}$ & $\mathrm{Nt}$ & $\mathrm{Nt}_{1}+\mathrm{Nt}_{2} / 2$ & $\begin{array}{c}\text { Production } \\
\left(\mathrm{g} \text { for } 6 \mathrm{~m}^{2}\right)\end{array}$ \\
\hline January & 0.095 & - & 63 & - & - \\
February & 0.108 & 0.013 & 87 & 75 & 0.975 \\
March & 0.135 & 0.027 & 58 & 72.5 & 1.957 \\
April & 0.130 & -0.005 & 47 & 52.5 & -0.262 \\
May & 0.132 & 0.002 & 61 & 54 & 0.108 \\
June & 0.147 & 0.015 & 82 & 71.5 & 1.072 \\
July & 0.165 & 0.018 & 70 & 76 & 1.368 \\
August & 0.149 & -0.016 & 72 & 71 & -1.152 \\
Total C1 & & & & & 4.066 \\
September & 0.083 & 0.083 & 82 & 41 & 3.403 \\
October & 0.100 & 0.017 & 62 & 72 & 1.224 \\
November & 0.105 & 0.005 & 74 & 68 & 0.340 \\
December & 0.100 & -0.005 & 52 & 63 & -0.315 \\
Total C2 & & & & & 4.652 \\
Total & & & & & 8.718 \\
\hline
\end{tabular}

$W t$ mean weight variation of a cohort between $\mathrm{t}_{1}$ and $\mathrm{t}_{2}, W t_{1}$ and $W t_{2}$ mean fresh weights of a cohort at times $\mathrm{t}_{1}$ and $\mathrm{t}_{2}, N t$ number of individuals in a cohort at times $\mathrm{t}, N t_{1}$ and $N t_{2}$ numbers of individuals in a cohort at times $t_{1}$ and $t_{2}$
Data on the species' mode of reproduction are very scarce and based on old and incomplete observations. To our knowledge, the present study is the first providing on the life cycle of $N$. falsa. Fauvel (1923) stated that the species reproduces in an epitokous state. However, ecological plasticity in the mode of reproduction has been observed for several species of polychaetes and particularly for nereidid polychaetes (see review by Giangrande 1997). For example, individuals of Perinereis cultrifera reproduce with or without the morphological modifications which are characteristic of epitoky depending on geographical origin. This species is particularly interesting since it occupies the same habitat as $N$. falsa (rocky shores) and is present in our study site. The reproduction of $P$. cultrifera in the English Channel and the French Atlantic coast is of an epitokous type and has been observed from May to June and sometimes July (Fauvel 1916; Herpin 1925; Fage and Legendre 1927; Durchon 1951; Cazaux 1965; Scaps et al. 1992). In the Arcachon Basin (Cazaux 1965) and on the north coast of Brittany, P. cultrifera (Scaps et al. 1992) has a 3-year lifespan. Along the Atlantic coast of El Jadida (Morocco), the reproduction of $P$. cultrifera is of an atokous type and spawning occurs from April until the end of May (Rouhi et al. 2008). In the Mediterranean Sea, mature specimens are atokous in Marseille (Peres and Rancurel 1948) and on the west coast of Algerian in the Bay of Algiers (Durchon 1957; Marcel 1962; Rouabah et al. 2008). In the Bay of Algiers, the lifespan of the species probably does not exceed two years and the reproductive period spans most of the year, but reproduction is most intense in spring from March to May (Rouabah et al. 2008). Reproduction of $P$. cultrifera is of an epitokous type in the Venice lagoon in Italy (Ansaloni et al. 1986), at Salammbô near Tunis (Zghal and Ben Amor 1989) and at Annaba on the east coast of Algeria near the Tunisian border (Rouabah and Scaps 2003a). At Annaba, P. cultrifera has a 3-year lifespan and spawning occurs in late April/early May (Rouabah and Scaps 2003a, b). The existence of two modes of reproduction in this species (atoky and epitoky) led Marcel (1962) and Zghal and Ben Amor (1989) to split the species into two physiologically different subspecies ("races"), while the observations of Scaps et al. (2000), Roubah and Scaps (2003b) and Roubah et al. (2009) indicated that " $P$. cultrifera" may represent a complex of species.

Our study showed that $N$. falsa from the coast of El Kala has a synchronous oogenesis. Similar results have been obtained for other species of nereidid polychaetes such as P. cultrifera (Rouabah and Scaps 2003a) and Platynereis dumerilii (Fischer and Dorresteijn 2004). In contrast, Zribi et al. (2007) showed that Perinereis macropus from the Gulf of Gabes (Tunisia) has an asynchronous oogenesis, with the female individual bearing oocytes of quite different diameters. 
Table 2 Comparison of the production/biomass ratio (P/B) in some species of polychaetous annelids

\begin{tabular}{lllll}
\hline Family & Species & P/B & Site & Authors \\
\hline Arenicolidae & Arenicola marina & 1.14 & Grevelingen estuary, North Sea & Wolff and Wolff (1977) \\
Nephthyidae & Nephthys hombergii & 1.9 & Lynher estuary, English Channel & Warwick and Price (1975) \\
Nereididae & Nereis diversicolor & $3.9-4.6$ & Bou Regreg, Morocco & Gillet (1993) \\
& Nereis diversicolor & $1.7-1.9$ & Oued Souss, Morocco & Aït Alla et al. (2006) \\
& Nereis falsa & 1.07 & El Kala, Algeria & Present work \\
& Perinereis cultrifera & 2.3 & El Jadida, Morocco & Rouhi et al. (2008) \\
Owenidae & Owenia fusiformis & 0.89 & English channel & Ménard et al. (1989) \\
Spionidae & Scolelepis squamata & 2.0 & Morocco & Bayed et al. (2006) \\
\hline
\end{tabular}

Data on the reproductive biology of nereidid polychaetes from the east coast of Algeria and the coast of Tunisia are very scarce. Nevertheless, Rouabah and Scaps (2003a) studied the life cycle and population dynamics of $P$. cultrifera in the area of Annaba, about $30 \mathrm{~km}$ west to our study site. It should be noticed that we did not find individuals of $N$. falsa in the site studied by Roubah and Scaps in $(2003 \mathrm{a}, \mathrm{b})$, while these two species co-occur on the coast of El Kala.

Nereis falsa has smaller mature oocytes (diameter of 160-210 $\mu \mathrm{m}$, mean $165 \mu \mathrm{m}$ ) than $P$. cultrifera (diameter from 220 to, mean $250 \mu \mathrm{m}$ ). The reproductive period of $P$. cultrifera is short and spawning occurs from the end of April to early May; that of $N$. falsa is longer with spawning occurring from the end of July to early September. Oogenesis in $P$. cultrifera takes 16 months, while that in $N$. falsa takes less than one year. So, these two co-occurring nereids show clear differences in reproductive traits. The reproductive season of $P$. macropus stretches from March to June in the Gulf of Gabes in Tunisia, and mature oocytes range between 220 and $300 \mu \mathrm{m}$ in diameter with a mean of $250 \mu \mathrm{m}$ (Zribi et al. 2007). In contrast to $P$. cultrifera and $P$. macropus, which reproduce in spring at rising sea water temperature, $N$. falsa reproduces in summer when sea water temperature is at its maximum. In our study site, there are three species of nereids co-occurring in the same habitat ( $N$. falsa, P. cultrifera and $P$. dumerilii) but only the life cycles of $N$. falsa and $P$. cultrifera have been investigated in this area. The life cycle of $P$. dumerilii, well known from some other geographical locations, remains to be studied for the coast of El Kala in order to compare all three species with respect to their reproductive characteristics.

The values of the mean annual biomass $(B=1.36 \mathrm{~g}$ $\mathrm{m}^{-2}$ year $\left.^{-1}\right)$ and the secondary production $(P=1.45 \mathrm{~g}$ $\mathrm{m}^{-2}$ ) of $N$. falsa at El Kala National Park are among the lowest recorded for polychaetes. The known $P / B$ ratios of polychaete worms range between 0.89 and 4.6 year $^{-1}$ (Table 2). The $\mathrm{P} / \mathrm{B}$ ratio value of $1.07 \mathrm{year}^{-1}$ for the $N$. falsa population of El Kala is similar to those reported for Owenia fusiformis in the English Channel (0.89 year $^{-1}$ ) and Arenicola marina in the North Sea $\left(1.14\right.$ year $\left.^{-1}\right)$ but is lower than those for polychaete worms from North Africa (e.g. $\mathrm{P} / \mathrm{B}=2.3$ year $^{-1}$ for $P$. cultrifera on the Atlantic coast of El Jadida, Morocco; Rouhi et al. 2008).

\section{References}

Abdenour C, Smith BD, Boulakoud MS, Samraoui B, Rainbow PS (2000) Trace metals in marine, brackish and freshwater prawns from north-east Algeria. Hydrobiologia 432:217-227

Ait Alla A, Gillet P, Deutsch B, Bergayou H, Moukrim A (2006) Respones of Nereis diversicolor (Polychaeta, Nereididae) populations to reduced wastewater discharge in the polluted estuary of oued Souss, bay of Agadir, Morocco. Estuar Coast Shelf Sci 70:633-642

Alliani S, Meloni R (1999) Dispersal strategies of benthic species and water current variability in the Corsica Channel. Scientia Marina 63:137-145

Andrea P, Giancarlo MJ (2003) La Fauna del Parco Nazionale del Circeo. Progetto "Parchi in qualità" ovvero "applicazione pilota del Sistema di Gestione Ambientale nelle aree naturali protette". ENEA, pp 1-81

Ansaloni L, Pellizzato M, Zunarelli-Vandini R (1986) Policheti di interessse economiconella laguna di Venezia. Nova Thalassia 8:641-642

Arana IL, Diaz OD (2006) Polychaeta (Annelida) associated with Thalassia testudinum in the northeastern coastal waters of Venezuela. Rev Biol Trop Int J Trop Biol Conserv 54:971-978

Baez D, Ardila NE (2003) Polychaetes (Annelida: Polychaeta) of the Colombian Caribbean. Biota Colomb 4:89-109

Bayed A, Cherkaoui F, Glémarec M (2006) Population dynamics of Scolelepis squamata (Annelida: Polychaeta) from a Northwest African beach. Cah Biol Mar 47:143-155

Beldi H, Gimbert F, Maas S, Scheiffer R, Soltani N (2006) Seasonal variations of $\mathrm{Cd}, \mathrm{Cu}, \mathrm{Pb}$ and $\mathrm{Zn}$ in the edible mollusc Donax trunculus (Mollusca, Bivalvia) from the gulf of Annaba, Algeria. Afr J Agr Res 1:85-90

Bouzeraa N, Abbes A, Soltani N (2004) Analyse des protéines chez trois espèces de bivalves vivant dans des milieux différents, la lagune El Mellah et le golfe d'Annaba. Bull INSTM 9:97-100

Cazaux C (1965) Evolution de Perinereis cultrifera (Grube) au cours d'un cycle annuel à Arcachon. Soc Linn Bord 101:1-18

Crisp D (1971) Energy flow measurements. In: Holme NA, Mc Intyre $\mathrm{AD}$ (eds) Methods for the study of marine benthos. Blackwell, Oxford, pp 197-279 
Day JH (1967) Polychaeta of Southern Africa. Part I. Errantia. British Museum (National History), London

Durchon M (1951) Les modalités de l'essaimage de Perinereis cultrifera Grube (Annélide Polychète) à Luc-sur-Mer (Calvados). Arch Zool Exp Gén 88:1-6

Durchon M (1957) Problèmes posés par le comportement des néréidiens au moment de leur reproduction. Ann Biol 33:31-42

Ertan Çinar M, Katağan T, Koçak F, Öztürk B, Ergen Z, Kocatas A, Önen M, Kirkim F, Bakir K, Kurt G, Dağli E, Açik S, Doğan A, Özcan T (2008) FaunaL assemblages of the mussel Mytilus galloprovincialis in and around Alsancak Harbour (Izmir Bay, eastern Mediterranean) with special emphasis on alien species. J Mar Syst 71:1-17

Fadlaoui S, Retière C (1995) Etude bionomique des communautés macrozoobenthiques des fonds subtidaux de la région de Sidi Boulbra (côte atlantique marocaine) et biogéographie des espèces. Bull Inst Sci Rabat 19:119-135

Fage L, Legendre R (1927) Pêches planctoniques à la lumière effectuées à Banyuls-sur-Mer et à Concarneau. Arch Zool Exp Gén 67:23-222

Fauvel P (1916) Annélides polychètes pélagiques provenant des yatchs « Hirondelle » et "Princesse alice». Résultats scientifiques des campagnes du Prince Albert $1^{\text {er }}$ de Monaco 48:1-152

Fauvel P (1923) Polychètes errantes. Faune de France. Lechevaliers, Paris

Fischer A, Dorresteijn A (2004) The polychaete Platynereis dumerilii (Annelida): a laboratory animal with spiralian cleavage, lifelong segment proliferation and a mixed benthic/pelagic life cycle. BioEssays 26:314-325

Pfaller JB, Bjorndal KA, Reich KJ, Williams KL, Frick, MG (2006) Distribution patterns of epibionts on the carapace of loggerhead turtles, Caretta caretta. J Mar Biol Ass UK 2: 1-4. Biodiversity records, published on-line, http://www.mba.ac.uk/jmba/pdf/5381. pdf

Gayanilo FC, Pauly D (1989) Announcing the release of version 1.1 of the Compleat ELEFAN Software Package. Fishbyte 7.2:20-31

Gayanilo FC, Soriano M, Pauly D (1988) A draft guide to the ELEFAN ICLARM Software Project 2, pp 1-70

Gayanilo FC, Sparre P, Pauly D (2005) FISAT II FAO ICLARM. Outils d'évaluation des stocks, pp 1-198

Giangrande A (1997) Polychaete reproductive patterns, life cycles and life histories: an overview. Ocean Mar Biol Ann Rev 35:323-386

Gillet P (1993) Impact de l'implantation d'un barrage sur la dynamique des populations de Nereis diversicolor (annélide polychète) de l'estuaire du Bou Regreg Maroc. J Rec Ocean 18:15-18

Glassom D, Branch GM (1997) Impact of predation by greater flamingos Phoenicopterus ruber on the macrofauna of two southern African lagoons. Mar Ecol Prog Ser 149:1-12

Guerra-Garcia JM, Garcia-Gomez JC (2004) Polychaete assemblages and sediment pollution in a harbour with two opposing entrances. Helgol Mar Res 58:183-191

Guerra-Garcia JM, Gonzales-Villa FJ, Garcia-Gomez JC (2003) Aliphatic hydrocarbon pollution and macrobenthic assemblages in Ceuta harbour: a multivariate approach. Mar Ecol Prog Ser 263:127-138

Herpin R (1925) Recherches biologiques sur la reproduction et le développement de quelques annelides polychètes. Bull Soc Sci Nat Ouest Fr 4:1-250

Marcel R (1962) Cycle annuel de Perinereis cultrifera Grube (Annélide Polychète) à Alger. Mém Soc Sci Nat Cherbourg 19:39-54

Ménard F, Gentil F, Dauvin JC (1989) Population dynamics and secondary production of Owenia fusioformis Delle Chiaje
(Polychaeta) from the Bay of Seine (eastern English Channel). J Exp Mar Biol Ecol 133:151-167

Peres JM, Rancurel P (1948) Observations sur la ponte de Perinereis cultrifera Grube dans le golfe de Marseille. Bull Soc Zool Fr 73:97-100

Posey MH, Alphin TD, Cahoon LB, Lindquist DG, Mallin MA, Nevers MB (2002) Top-down versus bottom-up limitation in benthic infaunal communities: direct and indirect effects. Estuaries 25:999-1014

Posey MH, Alphin TD, Cahoon LB (2006) Benthic community responses to nutrient enrichment and predator exclusion: influence of background nutrient concentrations and interactive effects. J Exp Mar Biol Ecol 330:105-118

Rouabah A, Scaps P (2003a) Life cycle and population dynamics of the Polychaete Perinereis cultrifera from the Algerian Mediterranean coast. Mar Ecol PSZN 24:85-99

Rouabah A, Scaps P (2003b) Two-dimensional electrophoresis analysis of proteins from epitokous forms of the polychaete Perinereis cultrifera from the English Channel and the Mediterranean Sea. Cah Biol Mar 44:227-236

Rouabah L, Rouabah A, Ferroudj S, Scaps P (2008) Comparison of the life cycles of two populations of the polychaete Perinereis cf. cultrifera from the Bay of Algiers (Mediterranean Sea). Sci Mar 72:769-778

Roubah A, Rouabah L, Tahar A, Scaps P (2009) Variations in paragnath number of the different morphs of the polychaete Perinereis cf. cultrifera in relation to geographical location and type of reproduction. Am J Sci Res 1:12-22

Rouhi A, Gillet P, Deutsch B (2008) Reproduction and population dynamics of Perinereis cultrifera (Polychaeta: Nereididae) of the Atlantic coast, El Jadida, Morocco. Cah Biol Mar 49:151-160

Sanchez-Moyano JE, Garcia-Adiego EM, Estacio FJ, Garcia-Gomez JC (2001) Influence of the density of Caulerpa prolifera (Chlorophyta) on the composition of the macrofauna in a meadow in Algeciras Bay (Southern Spain). Cienc Mar 27:47-71

Scaps P, Retière C, Desrosiers G, Miron G (1992) Dynamique d'une population de Perinereis cultrifera (Grube) de la côte nord de Bretagne. Cah Biol Mar 33:477-494

Scaps P, Roubah A, Leprêtre A (2000) Morphological and biochemical evidence that Perinereis cultrifera (Polychaeta: Annelida) is a complex of species. J Mar Biol Ass UK 80:735-736

Sifi K, Chouahda S, Soltani N (2007) Biosurveillance de l'environnement par la mesure de biomarqueurs chez Donax trunculus (L., 1758) dans le golfe d'Annaba, (Algérie). Mésogée 63:11-18

Thiel M, Gutow L (2005) The ecology of rafting in the marine environment. II. The rafting organisms and community. Ocean Mar Biol Ann Rev 43:279-418

Vittor BA (1984) Taxonomic field guide to the polychaetes of the northern gulf of Mexico. Minerals Management Service,Gulf of Mexico Regional Office, pp 1-154

Vittor BA (1997a) Florida Bay and Adjacent Waters Benthic Community assessment. U.S. Department of Commerce, National Oceanic and Atmospheric Administration National Ocean Service, Office of Ocean Resources Conservation and Assessment, pp 1-52

Vittor BA (1997b) Galveston Bay, Texas Benthic Community assessment. U.S. Department of Commerce, National Oceanic and Atmospheric Administration National Ocean Service, Office of Ocean Resources Conservation and Assessment, pp 1-33

Vittor BA (1998) Florida Bay, Florida Benthic Community assessment. U.S. Department of Commerce, National Oceanic and Atmospheric Administration National Ocean Service, Office of Ocean Resources Conservation and Assessment, pp 1-56

Warwick RM, Price R (1975) Macrofauna production in an estuarine mud flat. J Mar Biol Ass UK 55:1-18 
Wolf WJ, Wolff L (1977) Biomass and production of zoobenthos in the Grevelingen estuary, the Netherlands. Estuar Coast Shelf Sci $5: 1-24$

Zghal F, Ben Amor Z (1989) Sur la présence en Méditerranée de la race épitoque de Perinereis cultrifera (Polychète). Arch Inst Pasteur Tunis 66:293-301
Zribi S, Zghal F, Tekaya S (2007) Ovogenèse de Perinereis macropus Claparède 1870 (Annélide Polychète) dans le golfe de Gabès (Tunisie). C R Biol 330:199-204 